PRINT ISSN 1119-8362

Electronic ISSN 1119-8362
Full-text Available Online at

https://www.ajol.info/index.php/jasem

http://ww.bioline.org.br/ja
J. Appl. Sci. Environ. Manage.

Vol. 25 (5) 779-782 May 2021

\title{
Identification of Fungi Associated with Irvingia gabonensis (Ogbono) Seeds Spoilage in Benin City, Nigeria
}

\section{"OKOBIEBI, BO; EZENNIA, JN}

\author{
Department of Science Laboratory Technology, University of Benin, P.M. B 1154 Benin City, Edo State Nigeria. \\ *Corresponding Author Email: becky.obinyan@uniben.edu
}

\begin{abstract}
Irvingia gabonensis (Ogbono) is one of the forest tree species of great domestic importance and its postharvest shelve life is affected by various species of fungi. This study is to investigate the effect of various species of fungi that attack Irvingia gabonensis seeds in post-harvest. Ready to use cotyledons of Ogbono were obtained from six (6) markets in Benin City (New Benin market, Aduwawa market, Uselu market, Oba market, Ikpoba Hill market, Santana market) Edo State, in sterile transparent polyethylene bags and transported to the laboratory for analyses. The proximate composition of the Ogbono seeds was determined using standard protocols. The pour plate method was used for isolation using a potato Dextrose Agar which was supplemented with streptomycin. The fungi were isolated based on their cultural and microscopic characteristics. The result of the highest and lowest fungal counts were too numerous to count and $3.3 \times$ $10^{3} \mathrm{cfu} / \mathrm{g}$ respectively. A total of seven species of fungi were isolated and identified in this study which included Aspergillus flavus, Aspergillus fumigatus, Aspergillus niger, Mucor sp., Neurospora sp., Penicillium sp., and Rhizopus sp. Aspergillus flavus was the most prevalent fungi with prevalence rate of 48 (90.6\%), while Neurospora sp. was the least prevalent fungi with prevalent rate of $04(18.2 \%)$. The presence of these fungi especially Aspergillus species portrays a serious public health implication as regard food poisoning, mycotocosis and food security. Proper handling methods of Ogbono seeds, coupled with good orientation are necessary to ensure the safety of ogbono seeds.
\end{abstract}

\section{DOI: https://dx.doi.org/10.4314/jasem.v25i5.13}

Copyright: Copyright (C) 2021 Okobiebi and Ezennia. This is an open access article distributed under the Creative Commons Attribution License (CCL), which permits unrestricted use, distribution, and reproduction in any medium, provided the original work is properly cited.

Dates: Received: 20 March 2021; Revised: 27 April 2021; Accepted: 07 May 2021

Keywords: Irvingia gabonensis, Aspergillus spp, Market, cotyledon, fungal count

Irvinga gabonensis has a variety of important uses; both the fruit and kernel of the seed are edible and thus play important roles in nutritional supplements and food security in West and Central Africa, especially among rural dwellers and its fruits constitute a very important soup condiment in Nigeria Onyekwelu and Bernd (2006). It is rich in vitamin $\mathrm{C}$ and is widely consumed as a dessert fruit or snack throughout Western and Central Africa Leakey and Newton (1994). I. gabonensis is in high demand due to its nutritional, medicinal, economical worth and agricultural potentials Ndoye et al., (1997); Van, 2010. I. gabonensis is especially valued for their fat and protein rich seed a kernel which serves as a sauce thickening agent and oil Matos et al., (2009). A major setback in the sales and consumption of Irvingia seed kernels is their susceptibility to postharvest spoilage fungi and its intended health risks. Several studies have shown that Irvingia seed kernels displayed on shelves for sales in Nigerian markets are often contaminated with spoilage fungi like Aspergillus flavus and A. parasiticus and in turn the contaminated seed kernels possess aflatoxin, which are harmful to the consumers (Adebayo-Tayo et al., (2006); Iyayi et al., (2010); $\mathrm{Wu}$ and Khlangwiset, (2010). Consumption of high levels of aflatoxin in food has been reported to have caused illness among several hundreds of Kenyans in 2004, and leaving 125 people dead and it is estimated that more than 5 billion people in developing countries worldwide are at risk of chronic exposure to aflatoxins through contaminated foods Lewis et al., (2005); Strosnider et al., (2006). It becomes imperative therefore to handle postharvest Irvingia seeds in ways that would minimize postharvest fungal contamination. Hence the aim of this study was to isolate and identify the post-harvest fungal species that infest Irvingia gabonensis cotyledons sold in some markets within Benin City.

\section{MATERIALS AND METHODS}

Samples and Materials Preparation: Ready to be used cotyledons of Irvingia gabonensis (Ogbono) were obtained from different markets in Benin City (Oba market, Santana market, New Benin market, Ikpoba hill market, Uselu market and Aduwawa market) Edo state, Nigeria. The samples were transported to the LABORATORY for analyses.

Mycological Studies: Enumeration of total culturable fungi (THF): The medium of choice was the potato dextrose agar (PDA) with $10 \%$ tartaric acid using the spread plate method. The medium was prepared according to the manufacturer's (oxoid, Basingstoke, Hants) instructions and sterilized at $121^{\circ} \mathrm{C}, 15 \mathrm{psi}$ for 15 minutes before dispensing into sterile disposable petri plates. A $0.1 \mathrm{ml}$ aliquot of appropriate dilutions of sample was inoculated unto the media. The plates were incubated for 5-7 days at room temperature and 
colonies formed were counted and expressed as cfu/gram.

Identification of fungi isolated: Moulds that are utilizing petroleum hydrocarbon were identified based on preliminary and conventional methods. Pigment production was noted, and wet mount carried out by picking fungal colony onto grease free slide containing two drops of Lactophenol Cotton blue. This wet preparation was covered with cover slip and viewed under $\times 4$ and $\times 40$ objectives lenses. The methods have been previously reported by Chukwurah et al., (2007). Preliminary identification of Hydrocarbon utilizing fungi (moulds) was based on the keys and details on
Smith's Introduction to Industrial Mycology Onions et al., (1981).

\section{RESULTS AND DISCUSSION}

The fungal counts obtained from Irvingia gabonensis cotyledons in this work are shown in Table 1. The fungal count ranged from $3.3 \times 10^{3}$ to a large number of colonies that were too numerous to count (TNTC). This is contrary to the findings of Iyayi et al., (2010) whose findings had fungal count ranged between 2.7 $\mathrm{X} 10^{3}$ and $4.5 \times 10^{5}$ with the same dilution factor. This may be due to various environmental factors, climate, pre-harvest treatments and method of harvest.

Table 1: Total population of mould in the samples of Irvingia gabonensis collected from various markets in Benin City.

\begin{tabular}{lllll}
\hline $\begin{array}{l}\text { Source of } \\
\text { sample }\end{array}$ & $\begin{array}{l}\text { Volume } \\
\text { used }\end{array}$ & $\begin{array}{l}\text { Dilution } \\
\text { factor }\end{array}$ & $\begin{array}{l}\text { Number } \\
\text { of colony }\end{array}$ & $\begin{array}{l}\text { Fungal } \\
\text { count cfu/g }\end{array}$ \\
\hline Oba market & $1 \mathrm{ml}$ & $10^{2}$ & 33 & $3.3 \times 10^{3}$ \\
Oba market & $1 \mathrm{ml}$ & $10^{4}$ & 20 & $2.0 \times 10^{5}$ \\
Santana market & $1 \mathrm{ml}$ & $10^{2}$ & 90 & $9.0 \times 10^{3}$ \\
Santana market & $1 \mathrm{ml}$ & $10^{4}$ & 64 & $6.4 \times 10^{5}$ \\
New Benin market & $1 \mathrm{ml}$ & $10^{2}$ & 88 & $8.8 \times 10^{3}$ \\
New Benin market & $1 \mathrm{ml}$ & $10^{4}$ & 56 & $5.6 \times 10^{5}$ \\
Ikpoba hill market & $1 \mathrm{ml}$ & $10^{2}$ & 50 & $5.0 \times 10^{3}$ \\
Ikpoba hill market & $1 \mathrm{ml}$ & $10^{4}$ & TNTC & TNTC \\
Uselu market & $1 \mathrm{ml}$ & $10^{2}$ & 80 & $8.0 \times 10^{3}$ \\
Uselu market & $1 \mathrm{ml}$ & $10^{4}$ & 56 & $5.6 \times 10^{5}$ \\
Aduwawa market & $1 \mathrm{ml}$ & $10^{2}$ & 50 & $5.0 \times 10^{3}$ \\
Aduwawa market & $1 \mathrm{ml}$ & $10^{4}$ & 22 & $2.2 \times 10^{5}$ \\
\hline \multicolumn{5}{c}{ Key: TNTC $=$ Too numerous to count } \\
\end{tabular}

The fungal isolates found in the Irvingia gabonensis cotyledons samples analyzed at the different market locations are shown in Table 2-7. These isolates includes: Aspergillus flavus, Aspergillus fumigatus, Aspergillus niger, Mucor sp., Neurospora sp., Penicillium sp., and Rhizopus sp. Among these, Aspergillus niger, Rhizopus sp., Aspergillus flavus, Penicillium sp. and Mucor sp. This is in agreement with studies by Agrios, (1978) where these fungi had earlier been isolated from Irvingia cotyledons in storage and are recognized to be among the most common group of fungi that infect grains after harvest, and grow on them during storage Agrios, (1978).
Researches by Adebayo-Tayo et al., (2006), Iyayi et al., (2010) and Aboloma and Ogunbusola (2012) also isolated similar fungal species from Irvingia species cotyledons/seeds displayed for sale to consumers in some Nigerian markets. Aspergillus fumigatus and Neurospora spp were isolated in this study; this is contrary to other studies by Etebu and Bawo (2012) where Candida tropicalis, Phytophthora sp. and Fusarium oxysporum were isolated from the Irvingia gabonensis cotyledon. This may be due to differences in geographical location as both works were not conducted on the same location.

Table 2: Distribution of fungal isolates from samples in Oba market

\begin{tabular}{lll}
\hline Fungal isolates & No. of isolates & $\%$ frequency \\
\hline Aspergillus flavus & 05 & 25 \\
Aspergillus niger & 15 & 75 \\
Total & 20 & 100
\end{tabular}

Table 3: Distribution of fungal isolates from samples in Santana market

\begin{tabular}{lll}
\hline Fungal isolates & No. of isolates & \% Frequency \\
\hline Penicillium sp. & 04 & 6.3 \\
Aspergillus flavus & 48 & 90.6 \\
Rhizopus sp. & 02 & 3.1 \\
Total & 54 & 100
\end{tabular}

Table 4: Distribution of fungal isolates from samples in New Benin market

\begin{tabular}{lll}
\hline Fungal isolates & No. of isolates & \% frequency \\
\hline Aspergillus flavus & 36 & 56.3 \\
Aspergillus fumigatus & 03 & 4.7 \\
Rhizopus spp & 05 & 7.8 \\
Aspergillus niger & 09 & 14.1 \\
Mucor spp & 03 & 4.7 \\
Total & 56 & 100 \\
\hline
\end{tabular}




\begin{tabular}{|c|c|c|}
\hline Fungal isolates & No. of isolates & $\%$ frequency \\
\hline Aspergillus flavus & 40 & 80 \\
\hline Aspergillus fumigatus & 5 & 10 \\
\hline Penicillium spp & 5 & 10 \\
\hline Total & 50 & 100 \\
\hline
\end{tabular}

Table 6: Distribution of fungal isolates from samples in Uselu market

\begin{tabular}{lll}
\hline Fungal isolates & No. of isolates & \% Frequency \\
\hline Aspergillus fumigatus & 02 & 6.3 \\
Penicillium spp & 03 & 9.4 \\
Aspergillus flavus & 23 & 71.8 \\
Aspergillus niger & 04 & 12.5 \\
Total & 32 & 100 \\
\hline
\end{tabular}

Table 7: Distribution of fungal isolates from samples in Aduwawa market

\begin{tabular}{lll}
\hline Fungal isolates & No. of isolates & \% Frequency \\
\hline Aspergillus fumigatus & 09 & 40.9 \\
Aspergillus flavus & 04 & 18.2 \\
Aspergillus niger & 05 & 22.7 \\
Neurospora species & 04 & 18.2 \\
Total & 22 & 100 \\
\hline
\end{tabular}

Two fungi species were identified and isolated from the samples collected from Oba market namely Aspergillus flavus and Aspergillus niger as shown in Table 2. Of the two isolates Aspergillus niger had the highest prevalent rate of $15(75 \%)$ while Aspergillus flavus $5(25 \%)$.

Table 3-6 shows the prevalence of fungal isolates in the samples obtained from Santana market, New Benin market, Ikpoba hill market and Uselu market, where Aspergillus flavus 48 (90.6\%), 36(56.3\%), 40(80\%), $23(41.1 \%)$ respectively had the highest prevalent rate. Table 7 shows the prevalence of Fungal isolates from the samples obtained from Aduwawa market, where Aspergillus fumigatus $9(40.9 \%)$ had the highest prevalent rate. The dominance of Aspergillus sp. here is in agreement with Visconti et al., (2001) who reported that Aspergillus sp. are the pioneer fungal colonizers in seed-borne infection of Sorghum before other species of fungi arrive. One of the fungi isolated from this study of Irvingia cotyledons have the tendency to habour aflatoxin, which if ingested by man or animals, could lead to serious health challenges, and this fungi was Aspergillus flavus. Aflatoxins are produced primarily by the fungi Aspergillus flavus and Aspergillus parasiticus Wu and Khlangwiset (2010). Certain post-harvest conditions have been implicated as pre-disposing factors that lead to fungal attack and aflatoxin production in contaminated food, and some of these post-harvest conditions include storage conditions, duration, transportation and processing methods Wu and Khlangwiset (2010).

Conclusion: The ultimate result obtained from this study is while different fungi are present and responsible for Ogbono spoilage. The presence of these fungi especially Aspergillus species is most abundant and responsible for most food spoilage in Benin City and it portrays serious public health implication as regard food poisoning, mycotocosis and food security.
Acknowledgement: The authors will like to acknowledge Prof J. A. Okhuoya of the Department of Plant Biology and Biotechnology, University of Benin and Dr. Frank Orji for Federal Institute of Industrial Research Oshodin for assistance in mycological studies.

\section{REFERENCES}

Adebayo-Tayo, BC; Onilude, AA; Ogunjobi, AA; Gbolagade, JS; Oladapo, MO (2006). Detection of fungi and aflatoxin in shelved bush mango seeds (irvingia spp.) stored for sale in Uyo, Nigeria. Afr. J. Biotechnol. 5(19): 1729-1732

Aboloma, RI; Ogunbusola, EM (2012). Fungi associated with Irvingia gabonensis (Ogbono) and Colocynthis citrullus (Egusi) seeds sold in markets in Ado-Ekiti, Ekiti State, Nigeria. J. Nat. Prod. Plant Resour. 2(3): 423 - 426.

Agrios, NG (1978). Plant Pathology $2^{\text {nd }}$ ed. Academic Press, New York, 703pp.

Chukwurah, FE; Echeobi, D; Nneli, RO (2007). Hematological profile of immunodeficient (HIV) seropositive patients on antiretroviral (ARV) therapy implication of nutrition. Int. J. Res in Med. Sci. 1: 242-244.

Etebu, E; Bawo, DDS (2012). The effect of treatment methods and storage conditions on post-harvest disease and fungal quality of Irvingia gabonensis (Aubry-Lecomte ex-O'Rorke) Kernels. Food Sci. Qual. Manag. 10: $17-27$.

Iyayi, IM; Adewumi, ERK; Nassang, AL (2010). Microbial spoilage of Irvingia kernels in Benin City, Nigeria. Arch. Appl. Sci. Res. 2(5): 168176. 
Leakey, R; Newton. A (1994). Domestication of tropical trees for timber and non-timber products. MAB Digest 17: 67-68.

Lewis, L; Onsongo, M; Njapau, H; Schurz-Rogers, H; Luber, G; Kieszak, S; Nyamongo, J; Backer, L; Dahive, A; Misore, A; DeCock, K; Rubin, C; the Kenya Aflatoxicosis Investigation Group (2005). Aflatoxin contamination of commercial maize products during an outbreak of acute aflatoxicosis in eastern and central Kenya. Environ. Health Perspect. 113(12): 1763-1767.

Matos, L; Nzikou, JM; Matouba, E; Pandzou-Yembe, VN; Mapepoulou, TG; Linder, M. Desobry, S (2009). Studies of Irvingia gabonensis seeds kernels: Oil technological applications. Pak. J. Nutr. 8: 151-157.

Onions, AHS; Allsopp, D; Eggins, HOW (1981). Smith Introduction to Industrial Mycology. Edward Arnold, London, 398pp.

Onyekwelu, JC; Bernd, S (2006). Irvingia gabonensis. For. Ecol. Manag. 26(5): 14-22.
Ndoye, O; Pérez, MR; Eyebe, A (1997). The markets of non-timber forest products in the humid zone of Cameroon. Network No, 22 Rural Development Forest Network, Overseas Development Institute, London.

Van, M (2010). Irvingia potentials. J. Ethnopharmacol. 4: 280-285.

Visconti, A; Solfrizzo, M; De Girolamo, A (2001). Determinationof fumonisms B1 and B2 in corn and corn flakes by liquid chromatography with immunoaffinity column clean up: collaborative study. Assoc. Off. Anal. Chem. Int. (AOAC) 84: $1828-1837$.

Wu, F; Khlangwiset, P (2010). Health economic impacts andcost-effectiveness of aflatoxin reduction strategies in Africa: Case studies in biocontrol and postharvest interventions. Food Addit. Contam. 27: 496-509 